\title{
Prevalence of ischaemic heart disease and associations with serum lipoproteins in subjects aged 45 to 64 years The Speedwell study
}

\author{
D BAINTON, C J BURNS-COX, P C ELWOOD, B LEWIS, N E MILLER, K MORGAN, \\ P M SWEETNAM \\ From the Avon Area Health Authority, and Frenchay Hospital, Bristol; MRC Epidemiology Unit, Cardiff; and St \\ Thomas's Hospital, London
}

SUMMARY A longitudinal study has been set up to examine the incidence of ischaemic heart disease and its associations with serum lipoproteins including high density lipoprotein cholesterol and its subfractions, certain haemostatic factors, and other "risk" factors. We report here on our pilot study findings.

Cross-sectional data were available on 283 men and 68 women aged 45 to 64 representing $85 \%$ of the available population randomly selected from the lists of 16 general practitioners.

Reproducibility of the measurements of total serum cholesterol, triglyceride, and low density lipoprotein cholesterol was acceptable. The reproducibility of some of the other serum lipid fractions, for example high density lipoprotein cholesterol, was less good, in part because of the small range of the values found for these components.

Univariate associations of physical and behavioural characteristics and serum lipoproteins of men and women, with and without ischaemic heart disease, disclosed small and statistically nonsignificant differences except for levels of blood pressure. In particular, there was no significant difference in mean levels of serum high density lipoprotein cholesterol between men with ischaemic heart disease $(0.91 \mathrm{mmol} / \mathrm{l})$ and men without it $(0.94 \mathrm{mmol} / \mathrm{l})$.

In examining our data for the determinants of serum high density lipoprotein cholesterol using a linear multiple regression model, sex, serum high density lipoprotein cholesterol, and very low density lipoprotein triglyceride were the major factors, each individually explaining about $7 \%$ of the variance of serum high density lipoprotein cholesterol levels. In addition, alcohol intake and obesity each explained a further $2 \%$ of the variance.

The experience of the pilot study has led to modifications in the collection of blood samples and the subsequent estimation of lipid fractions.

In 1975, Miller and Miller ${ }^{1}$ published their hypothesis in which they suggested that reduced levels of plasma high density lipoprotein might accelerate the development of atherosclerosis and, in turn, ischaemic heart disease. We considered that the evidence marshalled for that paper, together with new data, was sufficient to justify the establishment in Bristol of a longitudinal study whose main objective would be the examination of the association of plasma high density lipoprotein cholesterol levels and the development subsequently of ischaemic heart disease.

Accepted for publication 5 January 1982
In order to examine the feasibility of such a study, we have carried out a pilot study whose principal aims were to determine (a) the likely response rate, (b) the feasibility of collecting fasting samples of blood, and (c) the suitability of certain laboratory methods for the longitudinal study. We report here on the findings of the pilot study which includes only data on prevalent ischaemic heart disease. Since we began this study other workers have reported their findings on the association of plasma high density lipoprotein and incidence of ischaemic heart disease. In these centres high density lipoprotein data were already available, ${ }^{2}$ 
or were obtained from deep frozen samples which had been collected two years previously. ${ }^{3}$

\section{Patients and methods}

The patients on the lists of 16 general practitioners based at two health centres serving adjoining areas of mixed social class were identified by age and sex and a random sample of 400 men and 100 women aged between 45 to 64 years was drawn. The reasons for choosing this number was that in men we wished to examine the levels of plasma high density lipoprotein in those with and without ischaemic heart disease. The expected lower prevalence of ischaemic heart disease in women would have necessitated a larger number of women to obtain estimates with reasonable precision, and we did not attempt this.

For both sexes we wished to examine the relation of high density lipoprotein to variables (other than ischaemic heart disease) such as low density lipoprotein cholesterol, very low density lipoprotein triglycerides, and obesity-data which would be available for every subject.

Subjects were asked to attend a local clinic where a history was obtained by questionnaire to determine a present or past history of ischaemic heart disease, ${ }^{4}$ risk factors for this condition, and certain variables which are known to influence lipid metabolism. Subjects were measured for height, weight, and skinfold thickness, using standard anthropometric methods. ${ }^{5}$ Casual blood pressure was measured in the left arm, using the Hawksley random zero instrument. ${ }^{6}$ Diastolic blood pressure was recorded at the point of muffling (phase 4). A resting 12 lead electrocardiogram was recorded using a Mingograph 34 machine. Subjects were asked to attend the clinic again a few days later in the fasted state and venous blood samples were obtained with minimal stasis. They had been given instructions to avoid food and drink (apart from water) for a period of 14 hours before the venepuncture was due. In the case of shift workers or perma- nent night workers the appointment was arranged so that the fasting interval could be achieved.

Duplicate blood samples were taken from $10 \%$ of subjects to test the reproducibility of the measurements. Blood for lipid measurements was centrifuged 30 minutes after clotting at room temperature, and serum samples were transported in ice-water to the laboratory. Blood collection was delayed by an interval of two weeks for any subject with a recent history of minor illness, or by three months for a patient recovering from a major illness.

Lipoprotein lipids were quantified as follows (see Table 1): after addition of sodium dodecyl sulphate to an aliquot of serum, very low density lipoprotein was separated by centrifugation and the infranatant (containing low density lipoprotein and high density lipoprotein) was isolated by aspiration with a finely drawn out Pasteur pipette. ${ }^{7}$ The very low density and the low density lipoprotein in a separate aliquot of serum were precipitated by addition of heparin and manganese chloride and sedimented by centrifugation. ${ }^{8}$ The supernatant (containing high density lipoprotein) was removed and the precipitate discarded. Cholesterol and triglyceride in whole serum and in the fraction containing high and low density lipoprotein (that is the sodium dodecyl sulphate infranatant) and the cholesterol in the fraction containing high density lipoprotein (that is the heparin/Mn supernatant) were measured directly by enzymatic procedures (Boehringer-Mannheim; catalogue nos. 187313 and 166448 ) in a Technicon AutoAnalyzer II. Peak heights were measured visually and Precilip (Boehringer-Mannheim) was used for quality control. Disodium EDTA was added to the heparin/ $\mathrm{MnCl}_{2}$ supernatants to chelate excess $\mathrm{Mn}^{++}$ions. ${ }^{9}$ Very low density lipoprotein triglyceride was calculated as serum triglyceride minus (low plus high density lipoprotein) triglyceride, and low density lipoprotein cholesterol as (low plus high density lipoprotein) cholesterol minus high density lipoprotein cholesterol. When duplicate samples of serum

Table 1 Summary of laboratory procedures and subsequent modifications for lipid estimations

\begin{tabular}{|c|c|c|c|}
\hline Sample & Serum $(1 \mathrm{ml})$ & Serum $(2 \mathrm{ml})$ & Serum $(2 \mathrm{ml})$ \\
\hline Procedure & $\begin{array}{l}\text { Assayed directly for cholesterol } \\
\text { and triglyceride (Technicon } \\
\text { AAII/enzymatic) }\end{array}$ & $\begin{array}{l}\text { Sodium dodecyl sulphate in } 0.15 \mathrm{M} \\
\mathrm{NaCl} \text { added (final conc, } 0.7 \% \mathrm{w} / \mathrm{v} \text { ) } \\
\text { Incubated at } 35^{\circ} \mathrm{C} \text { for } 2 \mathrm{~h} \\
\text { Centrifuged } \\
\text { Supernatant (VLDL) discarded } \\
\text { Infranatant (containing LDL and } \\
\text { HDL) assayed for cholesterol } \\
\text { and triglyceride (AAII) }\end{array}$ & $\begin{array}{l}\text { Heparin and } \mathrm{MnCl}_{2} \text { added (final } \\
\text { concs, } 183 \mathrm{u} / \mathrm{ml}, 0.045 \mathrm{M} \text { ) } \\
\text { Incubated at } 4^{\circ} \mathrm{C} \text { for } 30 \mathrm{~min} \\
\text { Centrifuged } \\
\text { Precipitate (VLDL plus LDL) } \\
\text { discarded } \\
\text { Supernatant (containing HDL) } \\
\text { assayed for cholesterol (AAII) }\end{array}$ \\
\hline Modifications & $\begin{array}{l}\text { EDTA-plasma used; centrifugal } \\
\text { analyser used for both lipids }\end{array}$ & $\begin{array}{l}\text { Preparative ultracentrifugation } \\
\text { used to isolate VLDL }\end{array}$ & $\begin{array}{l}\text { Final } \mathrm{MnCl}_{2} \text { conc increased to } \\
0.09 \mathrm{M}\end{array}$ \\
\hline
\end{tabular}

LDL, low density lipoprotein; HDL, high density lipoprotein; VLDL, very low density lipoprotein. 
were sent from the clinic, the laboratory workers were unaware of their identity.

Plasma glucose was measured by the automated glucose oxidase method of Trinder. ${ }^{10}$

The prevalence of ischaemic heart disease was estimated by three criteria: the presence of angina and a history of myocardial infarction using the standard WHO questionnaire for both ${ }^{4}$ and by electrocardiographic abnormalities. All electrocardiograms were classified by one observer using the Minnesota code ${ }^{11}$ and subdivided into three groups: probable ischaemia (items 1-1, 1-2, 7-1); possible ischaemia (items 1-3, 4-1 to 4-3, 5-1 to 5-3); and no ischaemia (none of the above). ${ }^{12}$

Because of the small number of cases of ischaemic heart disease in the study, the univariate association of ischaemic heart disease with the various measurements has been recorded in this paper with all categories of ischaemic heart disease combined (any

Table 2 Study sample

\begin{tabular}{lclc}
\hline Population sample & $\begin{array}{c}\text { Men } \\
400\end{array}$ & $\begin{array}{l}\text { Women } \\
100\end{array}$ & $\begin{array}{l}\text { Total } \\
500\end{array}$ \\
\hline Moved away/not traced & 71 & 16 & 87 \\
Available population & 329 & 84 & 413 \\
Seen at clinic (lst visit) & $285^{\star}$ & 68 & 353 \\
Returned for blood sample & $284^{\star}$ & 68 & 352 \\
$\quad$ (2nd visit) & &
\end{tabular}

^Includes two subjects who were discovered not to be aged 45 to 64 at the time the sample was drawn.

Table 3 Reproducibility of lipid tests and plasma glucose duplicate pair analysis

\begin{tabular}{llll}
\hline Test & $\begin{array}{l}\text { No. of } \\
\text { pairs }\end{array}$ & $\begin{array}{l}\text { Overall mean } \\
(\text { mmolll) }\end{array}$ & $\begin{array}{l}\text { Coefficient of } \\
\text { variation (\%) }\end{array}$ \\
\hline Cholesterol & & & \\
$\quad$ Total & 42 & 6.09 & 3.4 \\
LDL & 41 & 4.67 & 5.9 \\
HDL & 42 & 1.00 & 21.2 \\
Triglyceride & 42 & 1.50 & $11 \cdot 0(5.3)^{\star}$ \\
$\quad$ Total & 41 & 0.61 & $29.2(15 \cdot 2)^{\star}$ \\
$\quad$ VLDL & 49 & 5.19 & 0.36 \\
Plasma glucose & 49
\end{tabular}

^Excluding one "rogue" pair with total triglyceride values of 2.65 and 4.00 and corresponding VLDL values of 1.07 and 2.47. ischaemic heart disease), except in consideration of high density lipoprotein cholesterol. Univariate associations of each category of ischaemic heart disease and the above measurements have been determined but are not recorded in this paper. The determinants of high density lipoprotein cholesterol concentration have been considered using eight variables, viz, age, sex, obesity as weight/height ${ }^{2},{ }^{13}$ alcohol consumption, smoking habit, a combined measure of physical activity at work and during leisure time, low density lipoprotein cholesterol, and very low density lipoprotein triglyceride. A multiple regression model was used to assess the association of each variate with high density lipoprotein cholesterol.

\section{Results}

The population drawn and seen by age and sex is shown in Table 2. After identifying 500 names from the lists of the doctors, 87 individuals could not be traced, leaving 413 potentially available subjects for the study. Of this number 353 were seen at the clinic where most of the data were obtained, and of these 352 returned in a fasted state for venepuncture, 284 men and 68 women. Two subjects (both male) were discovered to be outside the age range of the study. The data relating to these two individuals have been excluded leaving 282 male subjects for whom there were usable data. This represents an overall response rate of $85 \%$.

Reproducibility of the biochemical measurements has been expressed as the coefficient of variation. Reproducibility for plasma glucose, total cholesterol and triglyceride, and low density lipoprotein cholesterol was acceptable and is shown in Table 3. Reproducibility of the remaining lipoprotein fractions, though more difficult to interpret, appeared to be less acceptable. The minimal recordable difference between pairs of samples for cholesterol was $0.1 \mathrm{mmol} /$, which was $10 \%$ of the overall mean for high density lipoprotein cholesterol. Of $\mathbf{4 4}$ pairs of samples for high density lipoprotein cholesterol estimation, 17 had, in fact, differences of $0.1 \mathrm{mmol} / 1$ or less.

Table 4 Prevalence of ischaemic heart disease in men and women by age

\begin{tabular}{|c|c|c|c|c|}
\hline & \multicolumn{2}{|c|}{ Ages of men $(y)$} & \multicolumn{2}{|c|}{ Ages of women $(y)$} \\
\hline & 45 to 54 & 55 to 64 & 45 to 54 & 55 to 64 \\
\hline No. in sample & 144 & 139 & 28 & 40 \\
\hline $\begin{array}{l}\text { Angina } \\
\text { History of myocardial infarction } \\
\text { Ischaemia on electrocardiogram } \\
\text { Probable } \\
\text { Possible }\end{array}$ & $\begin{array}{rr}8 & (6 \%) \\
4 & (3 \%) \\
2 & (1 \%) \\
12 & (8 \%)\end{array}$ & $\begin{array}{r}14(10 \%) \\
11(8 \%) \\
6(4 \%) \\
14(10 \%)\end{array}$ & $\begin{array}{ll}0 & (0 \%) \\
0 & (0 \%) \\
1 & (4 \%) \\
5 & (18 \%)\end{array}$ & $\begin{array}{l}4(10 \%) \\
4(10 \%) \\
1(3 \%) \\
4(10 \%)\end{array}$ \\
\hline Any ischaemic heart disease ${ }^{\star}$ & $23(16 \%)$ & $32(23 \%)$ & $6(21 \%)$ & $11(28 \%)$ \\
\hline
\end{tabular}

*Note that the individual categories are not mutually exclusive and hence do not add up to the "any ischaemic heart disease" figure. 
The prevalence of various categories of ischaemic heart disease is shown in Table 4. The individual categories of ischaemic heart disease were not mutually exclusive but there is little overlap of categories, especially in the younger age group. The prevalence of ischaemic heart disease in women was slightly higher than in men but the number of female cases is extremely small and these rates lack precision. In the rest of the tables data referring to ischaemic heart disease in women have not been given for this reason.

Univariate associations of physical and behavioural characteristics of the men and women and the presence and absence of ischaemic heart disease disclosed small and statistically non-significant differences apart from levels of blood pressure. In men, systolic and diastolic blood pressure levels were higher in those with ischaemic heart disease compared with levels in those without ischaemic heart disease (mean systolic blood pressure with ischaemic heart disease 160 $\mathrm{mmHg}$ (SD 30), without ischaemic heart disease 144 $\mathrm{mmHg}$ (SD 25); mean diastolic blood pressure with ischaemic heart disease $89 \mathrm{mmHg}$ (SD 15), without ischaemic heart disease $85 \mathrm{mmHg}$ (SD 13)). Differences between mean systolic and mean diastolic blood pressure with and without ischaemic heart disease were statistically significant $(p<0.001$ and $p<0.05$, respectively). Differences in the same direction for systolic and diastolic blood pressure levels in women were observed.

The associations between ischaemic heart disease and total cholesterol, total triglyceride, the lipoprotein lipids, and plasma glucose are shown in Table 5. The differences in concentrations of these lipids and lipoprotein fractions in men with and without ischaemic heart disease were small, and did not achieve statistical significance. Plasma glucose was higher in men with ischaemic heart disease (Table 5), but the difference from levels in those without ischaemic heart disease did not achieve statistical significance. The association of ischaemic heart disease and high density lipoprotein cholesterol concentrations was analysed further for two male age groups by each category of ischaemic heart disease-angina, history of myocardial infarction, and possible and probable electrocardiographic evidence of ischaemic heart disease. Differences in the concentration of high density lipoprotein cholesterol within these ischaemic heart disease categories for all age groups with and without evidence of the disease were small, inconsistent, and did not achieve statistical significance (Table 6).

Consideration of the eight variates singly as deter-

Table 5 Serum lipid and lipoprotein concentrations and plasma glucose in men with and without ischaemic heart disease

\begin{tabular}{|c|c|c|c|c|}
\hline \multirow[t]{2}{*}{ Variable } & \multicolumn{2}{|c|}{ No ischaemic heart disease } & \multicolumn{2}{|c|}{ Any ischaemic heart disease } \\
\hline & No. of subjects & $\operatorname{Mean}(S D)(\mathrm{mmol} / \mathrm{l})$ & No. of subjects & $\overline{M e a n}(S D)(\mathrm{mmol} / \mathrm{l})$ \\
\hline \multicolumn{5}{|l|}{ Cholesterol } \\
\hline $\begin{array}{l}\text { Total } \\
\text { HDL } \\
\text { LDL } \\
\text { HDL/Total (\%) }\end{array}$ & $\begin{array}{l}226 \\
226 \\
226 \\
225\end{array}$ & $\begin{array}{l}5.75(0.96) \\
0.94(0.43) \\
4.33(1.00) \\
16.8(8.1)\end{array}$ & $\begin{array}{l}52 \\
54 \\
54 \\
52\end{array}$ & $\begin{array}{c}5.77(0.93) \\
0.91(0.46) \\
4.30(0.95) \\
16.3(8.3)\end{array}$ \\
\hline Triglycerides & & & & \\
\hline $\begin{array}{l}\text { Total } \\
\text { VLDL } \\
\text { Plasma glucose }\end{array}$ & $\begin{array}{l}226 \\
226 \\
227\end{array}$ & $\begin{array}{l}1.55(0.89) \\
0.75(0.64) \\
5.26(1.39)\end{array}$ & $\begin{array}{l}52 \\
52 \\
55\end{array}$ & $\begin{array}{l}1.66(0.86) \\
0.84(0.70) \\
5.36(0.98)\end{array}$ \\
\hline
\end{tabular}

Note: Variation in numbers of subjects is explained by missing data.

Table 6 Serum high density lipoprotein $(H D L)$ cholesterol concentrations for men by age and category of ischaemic heart disease

\begin{tabular}{|c|c|c|c|c|c|c|}
\hline \multirow[t]{2}{*}{ Ischaemic heart disease category } & \multicolumn{2}{|c|}{45 to 54 years } & \multicolumn{2}{|c|}{55 to 64 years } & \multicolumn{2}{|c|}{45 to 64 years } \\
\hline & $\begin{array}{l}\text { No. of } \\
\text { subjects }\end{array}$ & $\begin{array}{l}\text { Mean } H D L \\
(S D)\end{array}$ & $\begin{array}{l}\text { No. of } \\
\text { subjects }\end{array}$ & $\begin{array}{l}\text { Mean } H D L \\
(S D)\end{array}$ & $\begin{array}{l}\text { No. of } \\
\text { subjects }\end{array}$ & $\begin{array}{l}\text { Mean } H D L \\
(S D)\end{array}$ \\
\hline $\begin{array}{l}\text { No angina } \\
\text { Angina } \\
\text { No history of myocardial infarction } \\
\text { History of myocardial infarction } \\
\text { No ischaemia on electrocardiogram } \\
\text { Possible ischaemia } \\
\text { Probable ischaemia } \\
\text { No ischaemic heart disease } \\
\text { Any ischaemic heart disease }\end{array}$ & $\begin{array}{r}135 \\
8 \\
139 \\
4 \\
129 \\
12 \\
2 \\
120 \\
23\end{array}$ & $\begin{array}{l}0.93(0.43) \\
0.71(0.21) \\
0.93(0.43) \\
0.65(0.24) \\
0.91(0.42) \\
1.00(0.49) \\
0.95(0.50) \\
0.93(0.43) \\
0.87(0.41)\end{array}$ & $\begin{array}{r}123 \\
14 \\
126 \\
11 \\
118 \\
13 \\
6 \\
106 \\
31\end{array}$ & $\begin{array}{l}0.94(0.44) \\
0.92(0.50) \\
0.94(0.43) \\
0.98(0.59) \\
0.95(0.43) \\
0.94(0.56) \\
0.88(0.51) \\
0.94(0.43) \\
0.94(0.50)\end{array}$ & $\begin{array}{r}258 \\
22 \\
265 \\
15 \\
247 \\
25 \\
8 \\
226 \\
54\end{array}$ & $\begin{array}{l}0.94(0.44) \\
0.85(0.43) \\
0.93(0.43) \\
0.89(0.53) \\
0.93(0.43) \\
0.97(0.52) \\
0.90(0.47) \\
0.94(0.43) \\
0.91(0.46)\end{array}$ \\
\hline
\end{tabular}

Note: Any ischaemic heart disease = angina and/or history of myocardial infarction and/or possible or probable ischaemia on electrocardiogram Data are not additive because one subject can have more than one of the individual ischaemic heart disease categories. 
Table 7 Serum high density lipoprotein (HDL) cholesterol concentrations and physical activity in men and women

\begin{tabular}{|c|c|c|c|c|c|c|c|c|}
\hline \multirow[t]{3}{*}{ Physical activity } & \multicolumn{4}{|c|}{ Leisure activity } & \multicolumn{4}{|c|}{ Work activity } \\
\hline & \multirow{2}{*}{$\frac{M e n}{N o .}$} & \multicolumn{3}{|c|}{ Women } & \multicolumn{2}{|l|}{$\overline{M e n}$} & \multicolumn{2}{|c|}{ Women } \\
\hline & & $\begin{array}{l}\text { Mean } H D L(S D) \\
(\mathrm{mmol} / \mathrm{l})\end{array}$ & No. & $\begin{array}{l}\text { Mean } H D L(S D) \\
(\text { mmolll })\end{array}$ & No. & $\underset{(\text { mmol/l) }}{\text { Mean } H D L(S D) I}$ & No. & $\underset{\text { (mmol/l) }}{\text { Mean } H D L(S D)}$ \\
\hline $\begin{array}{l}\text { None } \\
\text { Light } \\
\text { Heavy }\end{array}$ & $\begin{array}{l}148 \\
132\end{array}$ & $\begin{array}{l}0.90(0.43) \\
0.96(0.44)\end{array}$ & $\begin{array}{l}45 \\
23\end{array}$ & $\begin{array}{l}1.24(0.54) \\
1.21(0.41)\end{array}$ & $\begin{array}{r}99 \\
70 \\
111\end{array}$ & $\begin{array}{l}0.89(0.40) \\
0.88(0.43) \\
1.01(0.46)\end{array}$ & $\begin{array}{r}5 \\
30 \\
33\end{array}$ & $\begin{array}{l}1.42(0.61) \\
1.20(0.37) \\
1.23(0.58)\end{array}$ \\
\hline Total & $280^{\star}$ & $0.93(0.43)$ & 68 & $1.23(0.50)$ & $280^{\star}$ & $0.93(0.43)$ & 68 & $1.23(0.50)$ \\
\hline
\end{tabular}

$\star$ No data for two subjects of the original 282.

Table 8 Serum high density lipoprotein (HDL) cholesterol concentrations and alcohol consumption in men and women

\begin{tabular}{|c|c|c|c|c|}
\hline \multirow{2}{*}{$\begin{array}{l}\text { Alcohol } \\
\text { consumption } \\
\text { (ml/wk) }\end{array}$} & \multicolumn{2}{|l|}{ Men } & \multicolumn{2}{|c|}{ Women } \\
\hline & No. & $\begin{array}{l}\text { Mean } H D L \\
(S D) \\
(\text { mmolll })\end{array}$ & No. & $\begin{array}{l}\text { Mean } H D L \\
(S D) \\
(\text { mmol/l) }\end{array}$ \\
\hline $\begin{array}{c}0 \\
1 \text { to } 49 \\
50 \text { to } 99 \\
100 \text { to } 199 \\
200+\end{array}$ & $\begin{array}{r}20 \\
124 \\
46 \\
37 \\
53\end{array}$ & $\begin{array}{l}0.81(0.33) \\
0.91(0.46) \\
0.95(0.43) \\
0.98(0.49) \\
0.98(0.37)\end{array}$ & $\begin{array}{r}17 \\
34 \\
13 \\
4 \\
0\end{array}$ & $\begin{array}{l}1.04(0.33) \\
1.17(0.41) \\
1.65(0.70) \\
1.23(0.39) \\
-\end{array}$ \\
\hline Total & $280^{\star}$ & $0.93(0.43)$ & 68 & $1.23(0.50)$ \\
\hline
\end{tabular}

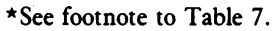

Table 9 Serum high density lipoprotein (HDL) cholesterol concentrations and obesity index (weight/height ${ }^{2}$ ) for men and women

\begin{tabular}{|c|c|c|c|c|}
\hline \multirow[t]{2}{*}{ Obesity index } & \multicolumn{2}{|l|}{ Men } & \multicolumn{2}{|c|}{ Women } \\
\hline & No. & $\begin{array}{l}\text { Mean } H D L \\
(S D) \\
(\text { mmolll })\end{array}$ & No. & $\begin{array}{l}\text { Mean } H D L \\
(S D) \\
(\text { mmolll) }\end{array}$ \\
\hline $\begin{array}{l}<20 \\
20 \text { to } 21.9 \\
22 \text { to } 23.9 \\
24 \text { to } 25.9 \\
26 \text { to } 27.9 \\
28 \text { to } 29.9 \\
\geqslant 30.0\end{array}$ & $\begin{array}{l}14 \\
27 \\
41 \\
79 \\
63 \\
37 \\
19\end{array}$ & $\begin{array}{l}1.09(0.33) \\
1.19(0.52) \\
0.84(0.33) \\
1.02(0.49) \\
0.87(0.41) \\
0.84(0.38) \\
0.68(0.21)\end{array}$ & $\begin{array}{r}4 \\
12 \\
12 \\
13 \\
15 \\
2 \\
9\end{array}$ & $\begin{array}{l}1.38(0.78) \\
1.18(0.32) \\
1.17(0.32) \\
1.49(0.55) \\
1.20(0.40) \\
0.85(0.64) \\
0.88(0.20)\end{array}$ \\
\hline Total & $280^{\star}$ & $0.93(0.43)$ & $67 \dagger$ & $1.23(0.50)$ \\
\hline
\end{tabular}

$\star$ See footnote to Table 7 .

†No data for one subject of the original 68 .

minants of high density lipoprotein cholesterol concentration for men and women showed no association with age or smoking habit. Exercise classified as light or heavy during leisure, and work activity classified as none, light, or heavy showed small positive associations with high density lipoprotein cholesterol concentrations in men, but small negative associations in women (Table 7). High density lipoprotein cholesterol levels rose with increasing alcohol intake in men and women (Table 8). As the index of obesity (weight $/$ height $^{2}$ ) rose in men and women, high density lipoprotein cholesterol concentrations decreased (Table 9). Concentrations of high density lipoprotein cholesterol fell as low density lipoprotein cholesterol

Table 10 Serum high density lipoprotein (HDL) and low density lipoprotein $(L D L)$ cholesterol concentrations in men and women

\begin{tabular}{|c|c|c|c|c|}
\hline \multirow[t]{2}{*}{$L D L(\mathrm{mmol} / \mathrm{l})$} & \multicolumn{2}{|l|}{ Men } & \multicolumn{2}{|c|}{ Women } \\
\hline & No. & $\begin{array}{l}\text { Mean } H D L \\
(S D) \\
(\text { mmol/l) }\end{array}$ & No. & $\begin{array}{l}\text { Mean } H D L \\
(S D) \\
(\text { mmolll) }\end{array}$ \\
\hline $\begin{array}{l}<3.0 \\
3.00 \text { to } 3.49 \\
3.50 \text { to } 3.99 \\
4.00 \text { to } 4.49 \\
4.50 \text { to } 4.99 \\
5.00 \text { to } 5.49 \\
5.50+\end{array}$ & $\begin{array}{l}23 \\
30 \\
55 \\
48 \\
57 \\
29 \\
38\end{array}$ & $\begin{array}{l}1.21(0.63) \\
1.04(0.44) \\
1.12(0.53) \\
0.89(0.36) \\
0.85(0.28) \\
0.76(0.15) \\
0.71(0.35)\end{array}$ & $\begin{array}{r}2 \\
6 \\
4 \\
12 \\
15 \\
10 \\
19\end{array}$ & $\begin{array}{l}2.10(0.71) \\
1.32(0.37) \\
1.38(0.34) \\
1.12(0.36) \\
1.36(0.69) \\
1.09(0.31) \\
1.12(0.44)\end{array}$ \\
\hline Total & $280^{\star}$ & $0.93(0.43)$ & 68 & $1.23(0.50)$ \\
\hline
\end{tabular}

Correlation coefficients-Men: $r=-0.37 \mathrm{p}<0.01$; women: $r=-0.24$ $\mathrm{p}<0.05$.

${ }^{\star}$ See footnote to Table 7 .

Table 11 Serum high density lipoprotein (HDL) cholesterol concentrations and very low density lipoprotein (VLDL) triglyceride concentrations in men and women

\begin{tabular}{|c|c|c|c|c|}
\hline \multirow{2}{*}{$\begin{array}{l}\text { Triglyceride } \\
(\mathrm{mmol} / \mathrm{l})\end{array}$} & \multicolumn{2}{|l|}{ Men } & \multicolumn{2}{|c|}{ Women } \\
\hline & No. & $\begin{array}{l}\text { Mean } H D L \\
(S D) \\
(m m o l / l)\end{array}$ & No. & $\begin{array}{l}\text { Mean HDL } \\
(S D) \\
(\mathrm{mmol} / \mathrm{l})\end{array}$ \\
\hline $\begin{array}{l}<0.2 \\
0.2 \text { to } 0.39 \\
0.4 \text { to } 0.59 \\
0.6 \text { to } 0.79 \\
0.8 \text { to } 0.99 \\
1.0 \text { to } 1.49 \\
1.5+ \\
\text { Not known }\end{array}$ & $\begin{array}{r}46 \\
44 \\
43 \\
39 \\
33 \\
37 \\
35 \\
3\end{array}$ & $\begin{array}{l}1.14(0.46) \\
1.02(0.39) \\
1.04(0.50) \\
0.88(0.47) \\
0.99(0.46) \\
0.68(0.21) \\
0.70(0.22) \\
0.57(0.21)\end{array}$ & $\begin{array}{r}23 \\
17 \\
6 \\
9 \\
4 \\
9 \\
0 \\
0\end{array}$ & $\begin{array}{l}1.38(0.44) \\
1.32(0.47) \\
1.12(0.45) \\
1.26(0.75) \\
0.83(0.22) \\
0.90(0.31) \\
-\end{array}$ \\
\hline Total & $280^{\star}$ & $0.93(0.43)$ & 68 & $1.23(0.50)$ \\
\hline
\end{tabular}


and very low density lipoprotein triglyceride rose in men and women (Tables 10 and 11).

The eight variates were included in a multiple regression model with, as the dependent variables in turn, the high density lipoprotein cholesterol and the log high density lipoprotein cholesterol concentrations. It was found that the assumptions of the model were better satisfied by choosing the log values of high density lipoprotein cholesterol as the dependent variable. The full model explained $31.9 \%$ of the total variance of $\log$ high density lipoprotein cholesterol concentration. Sex, low density lipoprotein cholesterol, and very low density lipoprotein triglyceride were each significantly associated with high density lipoprotein cholesterol concentration $(\mathrm{p}<0.001)$. Each variate explained individually around $7 \%$ of the variance in high density lipoprotein cholesterol concentration. Alcohol and obesity index were also highly significantly associated with high density lipoprotein cholesterol concentration, with each variate explaining about $2 \%$ of the variance.

Age, smoking habit, and physical activity were not associated with high density lipoprotein cholesterol level using this model. A five variate model excluding these same three factors explained $31.7 \%$ of the total variance of $\log$ high density lipoprotein cholesterol concentrations.

\section{Discussion}

The feasibility of undertaking a longitudinal study of the associations between ischaemic heart disease and plasma lipids and lipoproteins was supported by the satisfactory response of those available within the population sample.

We were particularly encouraged by the willingness of our subjects to fast overnight and attend a clinic the following morning. We made this easier for our subjects by starting the clinic relatively early $(7.15 \mathrm{am})$ and providing breakfast. In this way our subjects usually stopped off at the clinic on their way to work. Subjects who could not attend the clinic because they left for work before the clinic began were visited at home.

Reproducibilty of the lipid measurements was difficult to interpret because of the narrow range of values for some of the components. The coefficients of variation for high density lipoprotein cholesterol and very low density lipoprotein triglyceride were, however, sizeable, and were considered unacceptable for a longitudinal study. This has led to modifications in our methods, which include the use of $\mathrm{Na}_{2}$ EDTAplasma rather than serum, a reduction of the interval between venepuncture and lipoprotein quantification, the use of conventional preparative ultracentrifugation to isolate very low density lipoprotein, an increase in the final concentration of $\mathrm{MnCl}_{2}$ (to 0.09 M) used for the very low density lipoprotein/low density lipoprotein precipitation, ${ }^{14}$ and the measurement of lipid concentrations enzymatically in a centrifugal analyser (Table 1).

The prevalence of ischaemic heart disease in men was similar to that recorded by Reid and others in the Whitehall study using similar information from medical histories and electrocardiograms. ${ }^{15}$ The overall prevalence (any ischaemic heart disease) for men in the Whitehall study was $11.3 \%, 17 \%$, and $22.5 \%$ for men aged 40 to 49,50 to 59 , and 60 to 69 years, respectively.

The univariate associations of "risk" factors, including total cholesterol and triglyceride and the lipoproteins in particular, with ischaemic heart disease were not obvious except for blood pressure levels. Total cholesterol was marginally higher in those with ischaemic heart disease for both men and women. High density lipoprotein cholesterol was lower in men with ischaemic heart disease than in those without it. The ratio of high density lipoprotein/total cholesterol was marginally higher in men without ischaemic heart disease compared with men with it. The lack of clear association between these lipids and prevalent ischaemic heart disease is not unusual: for example the Framingham study showed no association between prevalence of ischaemic heart disease and total cholesterol. ${ }^{16}$

Because of the inverse associations of high density lipoprotein cholesterol and incidence of ischaemic heart disease reported from Framingham, ${ }^{2}$ Tromso, ${ }^{3}$ and Israel, ${ }^{17}$ it was of interest to consider determinants of high density lipoprotein cholesterol levels from our data. The independent contributions of sex, ${ }^{18-20}$ low density lipoprotein cholesterol, ${ }^{2122}$ very low density lipoprotein triglyceride, ${ }^{192123}$ alcohol, ${ }^{2425}$ and obesity 2023 in explaining variations of high density lipoprotein cholesterol are in keeping with other studies.

Having established the feasibility of a prospective study, we are currently recruiting for long-term follow-up all men aged 45 to 59 years registered with the same 16 general practitioners using the improved laboratory procedures. In view of the existing evidence that ischaemic heart disease may be related more strongly to the concentration of high density lipoprotein $2^{26}$ than to the other major high density lipoprotein subfraction 3 , measurements of both subfractions are being made, using an ultracentrifugal microprocedure recently developed in our laboratory. ${ }^{27}$

The authors received financial support for the study from ICI Pharmaceuticals Ltd, and The British Heart Foundation. 


\section{References}

1 Miller GJ, Miller NE. Plasma-high-density lipoprotein concentration and development of ischaemic heart disease. Lancet 1975; i: 16-9.

2 Gordon T, Castelli WP, Hjortland MC, Kannel WB, Dawber TR. High density lipoprotein as a protective factor against coronary heart disease: the Framingham study. Am J Med 1977; 62: 707-14.

3 Miller NE, Førde OH, Thelle DS, Mjøs OD. The Tromsø heart study. High density lipoprotein and coronary heart-disease: a prospective case-control study. Lancet 1977; i: 965-8.

4 Rose G. The diagnosis of ischaemic heart pain and intermittent claudication in field surveys. Bull WHO 1962; 27: 645-58.

5 Weiner JS, Lourie JA. Human biology: a guide to field methods. Oxford, Edinburgh: Blackwell Scientific Publications, 1969.

6 Wright BM, Dore CF. A random-zero sphygmomanometer. Lancet 1970; i: 337-8.

7 Ononogbu IC, Lewis B. Lipoprotein fractionation by a precipitation method. A simple quantitative procedure. Clin Chim Acta 1976; 71: 397-402.

8 Burstein M, Scholnick HR, Morfin R. Rapid method for the isolation of lipoproteins from human serum by precipitation with polyanions. $\mathcal{F}$ Lipid Res 1970; 11: 583-95.

9 Steele BW, Koehler DF, Azar MM, et al. Enzymatic determinations of cholesterol in high-density-lipoprotein fractions prepared by a precipitation technique. Clin Chem 1976; 22: 98-101.

10 Trinder P. Determination of blood glucose using an oxidase-peroxidase system with a non-carcinogenic chromogen. F Clin Pathol 1969; 22: 158-61.

11 Rose GA, Blackburn H. Cardiovascular survey methods. WHO Monogr Ser 1968; No 56.

12 Reid DD, Holland WW, Rose GA. An Anglo-American cardiovascular comparison. Lancet 1967; ii: 1375-8.

13 Khosla T, Lowe CR. Indices of obesity derived from body weight and height. Br $\mathcal{F}$ Prev Soc Med 1967; 21: 122-8.

14 Albers JJ, Warnick GR, Wiebe D, et al. Multi-laboratory comparison of three heparin-Mn2+ precipitation procedures for estimating cholesterol in high density lipoprotein. Clin Chem 1978; 24: 853-6.

15 Reid DD, Brett GZ, Hamilton PJS, Jarrett RJ, Keen H, Rose G. Cardiorespiratory disease and diabetes among middle-aged male civil servants. Lancet 1974; i: 469-73.
16 Friedman GD, Kannel WB, Dawber TR, McNamara PM. Comparison of prevalence, case-history and incidence data in assessing the potency of risk factors in coronary heart disease. Am $\mathcal{F}$ Epidemiol 1966; 83: 36678.

17 Goldbourt U, Medalie JH. High density lipoprotein cholesterol and incidence of coronary heart disease-the Israeli ischemic heart disease study. Am $\mathcal{F}$ Epidemiol 1979; 109: 296-308.

18 Brunner D, Weisbort J, Loebl K, et al. Serum cholesterol and high density lipoprotein-cholesterol in coronary patients and healthy persons. Atherosclerosis 1979; 33: 9-16.

19 Castelli WP, Cooper GR, Doyle JT, et al. Distribution of triglyceride and total LDL and HDL cholesterol in several populations: a cooperative lipoprotein phenotyping study. F Chronic Dis 1977; 30: 147-69.

20 Carlson LA, Ericsson M. Quantitative and qualitative serum lipoprotein analysis. Part 1. Studies in healthy men and women. Atherosclerosis 1975; 21: 417-33.

21 Nichols AV. Human serum lipoproteins and their interrelationships. Advances Biol Med Phys 1967; 11: 109-58.

22 Nikkilä E. Studies on the lipid-protein relationships in normal and pathological sera and the effect of heparin on serum lipoproteins. Scand F Clin Lab Invest 1953; 5, suppl 8.

23 Logan RL, Riemersma RA, Thomson M, et al. Risk factors for ischaemic heart disease in normal men aged 40: Edinburgh-Stockholm study. Lancet 1978; i: 949-55.

24 Castelli WP, Doyle JT, Gordon T, et al. Alcohol and blood lipids: the cooperative lipoprotein phenotyping study. Lancet 1977; ii: 153-5.

25 Williams P, Robinson D, Bailey A. High density lipoprotein and coronary risk factors in normal men. Lancet 1979; i: 72-5.

26 Gofman JW, Young W, Tandy R. Ischaemic heart disease, atherosclerosis and longevity. Circulation 1966; 34: $679-97$.

27 Eyre J, Hammet F, Miller NE. A micro-method for the rapid ultracentrifugal separation of human plasma high density lipoprotein subfractions, $\mathrm{HDL}_{2}$ and $\mathrm{HDL}_{3}$. Clin Chim Acta 1981; 114: 225-31.

Requests for reprints to Dr David Bainton, Avon Area Health Authority, Greyfriars, Lewin's Mead, Bristol BS1 2EE. 